\title{
Sylvia Pankhurst, the First World War and the struggle for democracy
}

Sylvia Pankhurst, la Première Guerre mondiale et la lutte pour la démocratie

\section{Katherine Connelly}

\section{CpenEdition}

\section{Journals}

\section{Electronic version}

URL: http://journals.openedition.org/rfcb/275

DOI: $10.4000 / \mathrm{rfcb} .275$

ISSN: 2429-4373

\section{Publisher}

CRECIB - Centre de recherche et d'études en civilisation britannique

\section{Printed version}

Date of publication: 15 January 2015

ISSN: 0248-9015

\section{Electronic reference}

Katherine Connelly, "Sylvia Pankhurst, the First World War and the struggle for democracy », Revue Française de Civilisation Britannique [Online], XX-1 | 2015, Online since 01 May 2015, connection on 19 April 2019. URL : http://journals.openedition.org/rfcb/275; DOI : 10.4000/rfcb.275

This text was automatically generated on 19 April 2019

\section{(c) $($ ) $\odot$ EY}

Revue française de civilisation britannique est mis à disposition selon les termes de la licence Creative Commons Attribution - Pas d'Utilisation Commerciale - Pas de Modification 4.0 International. 


\title{
Sylvia Pankhurst, the First World War and the struggle for democracy
}

\author{
Sylvia Pankhurst, la Première Guerre mondiale et la lutte pour la démocratie
}

\author{
Katherine Connelly
}

1 Throughout her life Sylvia Pankhurst was involved in a broad range of campaigns including the suffragette movement, the campaign against the First World War, the Communist movement, anti-fascism and support for the freedom of Ethiopia. One of the apparent contradictions in her shifts of emphasis took place in the course of the First World War.

In 1914 Sylvia Pankhurst was a leading militant suffragette campaigning for the representation of all women in Parliamentary democracy. However, when women were granted the vote over the age of $30 \mathrm{in}$ 1918, far from celebrating this as the culmination of the struggle in which she had campaigned, Sylvia was unconvinced that this measure could achieve the kind of democracy she hoped for. Instead, she championed the Bolshevik Revolution which she believed was creating a far more developed form of democracy and she asked British socialists to:

consider very seriously whether our efforts should not be bent on the setting aside of this present Parliamentary system under which the peoples suffer, and the substitution of it by a local, national, and international system, built up on an occupational basis, of which the members shall be but the delegates of those who are carrying on the world's work; and shall be themselves workers, drawn [ ... ] from the bench, the mine, the desk, the kitchen, or the nursery; and sent to voice the needs and desires of others like themselves. ${ }^{1}$

The changes in Sylvia Pankhurst's political activities in these years even confused and frustrated her fellow activists. Helena Swanwick, who in the First World War campaigned for peace alongside Sylvia Pankhurst in the Women's International League, would later recall that Sylvia:

was a very provoking colleague, owing to her habit of going her own separate way, even after she had joined others in hammering out an agreed way. There might have been give and take, and they would, perhaps, loyally carry out the agreed 
compromise, only to find that, like one of the hoops in "Alice's" game of croquet [in

Alice in Wonderland], Sylvia had wandered off to another part of the field. ${ }^{2}$

4 To understand why Sylvia Pankhurst's political ideas in 1918 were felt to be so different from those she held in 1914 requires an examination of the experiences she underwent during the First World War.

\section{The women's suffrage movement and the outbreak of War}

5 Discussions of divisions in the British women's suffrage movement have typically focused on tactical differences between different organisations. The most obvious divide was between the two largest and most prominent women's suffrage campaign organisations, the National Union of Women's Suffrage Societies (NUWSS), whose 'constitutionalist' suffragists used peaceful campaigning tactics, and the Women's Social and Political Union (WSPU), whose militant suffragettes resorted to direct action and civil disobedience. However, the outbreak of the First World War revealed divisions that cut across these organisations. Millicent Fawcett, the president of the NUWSS, and WSPU leaders Emmeline and Christabel Pankhurst, who also happened to be Sylvia's mother and older sister, argued that women owed loyalty to their nation state which in wartime took precedence over their demand to be recognised as citizens within that state and thus they suspended their votes for women's campaigns in favour of campaigns to support the war effort. All three adopted belligerently nationalistic positions during the war; by 1915 NUWSS leader Millicent Fawcett was proclaiming that it was 'akin to treason to talk of peace ', while the WSPU changed the title of its newspaper from The Suffragette to Britannia, and leading WSPU members toured the country denouncing workers taking strike action and attacking those who opposed the war as 'pro-German'. ${ }^{3}$

However, there were members within both organisations who were unhappy with their leaderships' overt nationalism. A section of leading NUWSS members left their organisation after it condemned them for helping to organise the 1915 International Women's Congress in the Hague which called for a negotiated peace. ${ }^{4}$ Opposition to the War within the WSPU came not from the official, national leadership but instead from a group of rank and file activists, dubbed 'freelance' suffragettes by historians Stanley and Morley. ${ }^{5}$ The lack of opposition within the official WSPU leadership, especially in contrast to the NUWSS, can partly be attributed to the splits that had taken place in the WSPU before the outbreak of War which in each case had seen activists with more socialist leanings depart from the organisation and join other groups. The split in 1907 saw the formation of the Women's Freedom League; after their expulsion from the WSPU in 1912 Frederick and Emmeline Pethick Lawrence joined the United Suffragists; and when Sylvia Pankhurst was ordered to leave the WSPU in January 1914 her East London branch of the WSPU became the East London Federation of the Suffragettes (ELFS). All three of these organisations adopted a critical stance towards the war effort. 


\section{Sylvia Pankhurst and the creation of a working-class suffragette movement}

7 At the heart of the split between the ELFS and the WSPU were conflicting ideas about the politics of the women's suffrage movement. Although the WSPU had been created in 1903 by women with strong ties to the labour and socialist movements, after Christabel Pankhurst took control of the leadership from late 1906 the organisation began to reflect her increasingly right-wing politics. The WSPU started discouraging the central involvement of working-class women as they relied less upon collective action in favour of more individualistic acts of heroism that would attract more public and press attention if conducted by society's wealthy and prominent women. In 1908 Christabel Pankhurst summarised the changing direction thus: 'it is especially the duty of women of distinction and influence to show their earnestness and devotion to this cause by taking part in the militant movement'. ${ }^{6}$ An exclusive focus was demanded on women's suffrage with members exhorted to reject 'class feeling' and party politics, although in practice this was targeted at removing the socialist and labour movement politics that had characterised the organisation at its inception. ${ }^{7}$ Indeed, the WSPU leadership condemned the measures taken by campaigners in contemporary struggles against social inequalities such as the strikes of male workers, Christabel Pankhurst even argued that men would be wrong to send a deputation to Parliament as the suffragettes did 'because they [men] have representatives sitting in the House of Commons'. ${ }^{8}$ Instead Christabel Pankhurst sought, although largely unsuccessfully, the support of the Conservative Party and the Ulster loyalists, neither of which had a long-standing commitment to women's suffrage, and both of which promoted a narrow and discriminatory view of political representation generally. ${ }^{9}$ Therefore, while Christabel Pankhurst sought the removal of the barrier to women's political representation, she did so largely because she identified with the interests of the existing state and, more widely, with the British Empire, and not because she identified with those struggling against other aspects of the discriminatory basis of that state.

8 After Christabel fled to Paris in 1912 to avoid a conspiracy charge, her strategy faced being undermined as her socialist sister Sylvia began to take on a leading role in the militant suffragette movement and created a branch which organised among workingclass women in the East End of London. Sylvia would later recall that Christabel demanded the East London branch separate from the WSPU on the basis of her objection to working women's involvement in the campaign. ${ }^{10}$ In the first edition of the ELFS's newspaper, The Woman's Dreadnought, Sylvia's editorial defended their insistence on building a working-class suffragette campaign:

Those Suffragists who say that it is the duty of the richer and more fortunate women to win the Vote, and that their poorer sisters need not feel themselves called upon to aid in the struggle appear, in using such arguments, to forget that it is the Vote for which we are fighting. The essential principle of the vote is that each one of us shall have a share of power to help himself or herself and us all. It is in direct opposition to the idea that some few, who are more favoured, shall help and teach and patronize the others. ${ }^{11}$

9 Therefore, Sylvia explicitly rejected the idea, promoted by Christabel, that society's wealthy women could represent the interests of working women. Furthermore, the ELFS identified their struggle with others facing repression by employers and the British state. 
The ELFS supported and recruited members from working women, particularly in the wave of strike action that became known as the Great Unrest, they worked closely with trade unions and when the First World War broke out Sylvia Pankhurst was in the middle of a visit to Ireland where she was gathering first-hand reports of a massacre of Irish civilians by British troops. ${ }^{12}$ Sylvia's trip to Ireland underlined her internationalism, which stressed that workers across national boundaries had more in common with each other than they did with their ruling class. Only three days before the outbreak of the First World War Sylvia implied that working people had nothing to gain from war when she argued that modern wars were waged solely for the material gain of society's elite:

All sorts of reasons that sound glorious and patriotic are invariably put forward in support of a declaration of war; but it is practically certain that every war of modern times has been fought with the purely materialistic object of forwarding the schemes and protecting the interests of powerful and wealthy financiers. ${ }^{13}$

\section{The East London Federation of the Suffragettes and the outbreak of War}

10 Sylvia's socialist materialist opposition to the War was shared by leading ELFS member Melvina Walker, a docker's wife, who wrote an article in The Woman's Dreadnought, titled 'Working Women and the War', just over a week after the outbreak of war, in which she argued against the growing nationalist tensions that were dividing communities in East London by evoking the solidarity German workers had shown to London dockers in their strike:

How strange! British transport workers - trade union men - are called upon to shoot down German transport workers, and it is not so very long ago, in the time of our industrial war - I mean the great Dock Strike - when we were fighting the large ship owners, we received with joy the news that these same men had sent us $£ 5,000$ to help us in our fight for better conditions. We said we would never forget their kindness, let us keep our word by treating all those German workers who are left behind in our midst with civility. ${ }^{14}$

11 Other anti-war ELFS members included Elsie Lagsding, whose brother became a Conscientious Objector, and Jessie Stephen, who joined the ELFS after resigning from the WSPU over its support for the war effort. ${ }^{15}$ However, not all ELFS members took this antiwar stance when Britain entered the War on 4 August 1914. Melvina Walker would later remember the effect of the pro-war propaganda campaign in the East End of London, which won support by promising a short, heroic and victorious war:

When War was declared, everybody who was "anybody" in Poplar [a borough in East London] threw himself or herself into the job of recruiting. [...]

Down came three or four 'buses filled with soldiers, and bands playing "It's a Long Way to Tipperary," "Rule Britannia" and other such songs to stir up the people. Each "bus displayed a white banner inscribed: "Roll Up Boys, A Free Ride to Berlin. Hundreds of men and women gathered round. Every man who walked up the steps to "sign on" was treated as a hero; cheers were continually rising. ${ }^{16}$

Sylvia Pankhurst immediately noticed the effects of this atmosphere on members of the ELFS when she returned from Ireland to find Norah Smyth and Jessie Payne, two of the organisation's leading members who lived in the same house with Sylvia, accepted the government's claim that Britain had entered the War to defend Belgium. She felt 'their minds all dazed and glamoured by the torrents of Press rhetoric, and the atmosphere of excitement 
and rumour growing apace in every street. ${ }^{17}$ The glamorisation of war rendered Sylvia's antiwar arguments distinctly less attractive, Sylvia later recalling:

They flinched from the huge conception that a perpetual reaching out for new fields of exploitation was inherent to the Capitalist system. To show them that the rivalry of the Governments to secure preferential opportunities for their Nationals was the vast master-cause of the War, was to thrust on them a vision of human Society, ruthless and without scruple as the grip of the boa-constrictor upon the lamb. It was to tear from them the tinsel and the glory, to send their souls shivering and naked into a grey, cold world of disillusion, peopled by harsh and revolting truths. ${ }^{18}$

13 Furthermore, beyond the acceptance of government rhetoric and an initially enthusiastic response to the pro-war propaganda, there were other reasons why people in East London became caught up in the war effort. The outbreak of war had destabilised the economy, workers were thrown out of work as industries restructured to cater for war production and the cost of food spiralled due partly to concerns over shortage of supply and partly due to opportunistic profiteering. ${ }^{19}$ These changes disproportionately hit the poorest in society and the effects were particularly felt in the impoverished East End. In December 1914 an East London man who had enlisted told the Dreadnought that when people asked the soldiers why they had joined up, they replied 'because we were starving'. ${ }^{20}$ Sylvia identified that similar pressures forced local women to work in the wartime industries:

I was surrounded by masses of poor women who had taken war work, soldiers' clothes and equipment, munitions, whatever came, as the sole means of keeping them and theirs from starvation. Inevitably they passed to war work as peace employment failed. ${ }^{21}$

At an ELFS special meeting to discuss the way forward, held two days after Britain entered the War, Sylvia acknowledged the constraints that this situation placed on the ELFS's activism: 'we could not say much against the war at present as so many people have relations in it that they will not listen yet.' ${ }^{22}$ Acknowledging the extent of local involvement in the war effort, combined with the initial wave of popular patriotic enthusiasm and the lack of a united perspective on the War within the ELFS, the ELFS decided on a list of five demands that the organisation could unite around. The first called on the government to take control of the food supply 'in order that all may feed or starve together, without regard to wealth or social position', and that working-class women be consulted on the price and distribution of food. The second called for government committees to provide work for men and women at the rates set by the trade unions, with 'women to be paid at equal rates with men for equal work'. The third called for the moratorium that applied to debts over £5 to be extended to those below, as these were the debts incurred by the poor and least able to pay. The fourth called for committees dealing with food prices, employment and relief to include working-class women. The fifth demand was votes for women. ${ }^{23}$ Though this did not require members to adopt an explicitly anti-war stance, the first four demands did insist that the War should not translate into increased suffering or exploitation for the working-class. However, the ELFS's stance did implicitly undermine the War in two ways. Firstly, the insistence that working people had different interests from their rulers countered the establishment's rhetoric any sacrifice was justified because nothing but the 'national interest' mattered in wartime. Secondly, the demand that workers' wages should be generally raised, and the price of food subject to democratic control to protect against profiteering, entailed shifting the cost of the war away from the poor and onto the more wealthy members of society. Sylvia Pankhurst demonstrated an awareness of the radical 
implications of this argument when she told an ELFS general meeting in 1915: 'If we can make employers lose instead of making profits we would bring the war to an end'. ${ }^{24}$

\section{Campaigning in the community}

The five demands constituted campaigning aims, but in the meantime the EFLS found itself confronted with the immediate problem of the intense distress the East End had been plunged into by the outbreak of War. The ELFS's local reputation for effective campaigning meant that it was to this organisation that many people turned for help, as Sylvia Pankhurst remembered: 'It was intensely gratifying to realize that so many women felt that the Suffragettes were their friends'. ${ }^{25}$ The ELFS established a Distress Bureau at its headquarters which helped women struggling with the wartime bureaucracy. Many women did not know how to apply for the separation allowance that was supposed to compensate for the absence of a son or husband who had joined the army. When women did apply they frequently found that the authorities lost their application forms and legal documents. When money was granted to wives and families, or in compensation to wounded soldiers, the amount was often wrong. Mistakes and delays had a far more devastating impact on poorer families who did not have the financial resources to subsist in the meantime. Sylvia took up numerous cases on behalf of soldiers and their families, writing to the relevant government departments to challenge decisions she regularly won improvements and the ELFS began to act 'as a Trade Union or a family solicitor might have done. ${ }^{26}$

Distress bureaus were soon set up at the four other ELFS offices across East London. The scale of destitution prompted the ELFS to go beyond providing legal advice and they began to organise schemes providing immediate practical assistance to local women and children. The five bureaus were soon offering free milk, baby-weighing and daily professional medical assistance. These were accompanied by five 'Cost Price Restaurants', the first set up less than a month after the outbreak of War, where local people who bought an inexpensive meal ticket were provided with a two-course meal, although the very poor were given these tickets for free and the ELFS ensured that customers were not aware who had paid and who was eating there for free. The ELFS also employed some local women, who had suddenly found themselves out of work, making maternity clothes and toys and created a nursery, run according to the Montessori method, to provide for the workers' children. This became a significant area of work for the ELFS; in January 1915 they were employing, in addition to their own organising and secretarial staff ${ }^{59}$. regular indoor workers on relief work of one kind or another, all but five of whom are on full time, and also a varying number of outworkers. ${ }^{27}$

Sylvia Pankhurst had misgivings about the establishment of these welfare services, as she did not want to see her organisation, which had strived so hard to empower working women to fight for their rights, turn into one which now treated those women as passive victims: 'organised relief, even the kindliest and most understanding, might introduce some savour of patronage or condescension, and mar our affectionate comradeship, in which we were all equals'. ${ }^{28}$ The ELFS took several measures to guard against this. Firstly, they insisted on paying all the adult workers at least $5 \mathrm{~d}$. an hour, thus ensuring that women were not paid less than the minimum wage a man in the area was paid (women were generally paid at a lower rate than men)..$^{29}$ Secondly, as the number of people approaching the ELFS for legal assistance increased, Sylvia created a new organisation at the beginning of 1915, the 
League of Rights for Soldiers' and Sailors' Wives and Relatives, in which she involved the women who wished to challenge decisions and encouraged them to take up their own grievances in a collective environment, supported by others in a similar position alongside help and expertise from ELFS members. Sylvia later recalled that 'it was my great joy that we were stimulating working women to speak up for themselves and their sort, and to master, despite their busy lives, the intricacies of Royal warrants and Army regulations, so as to secure the promised allowances, such as they were, for themselves and their neighbours. ${ }^{\prime}{ }^{30}$ The choice of names for their projects also reflected their aim of self-emancipation, by for example titling their organisation for legal redress the 'League of Rights', while Sylvia recalled that the restaurants were titled 'Cost Price' because 'the name should be a slogan against profiteering, and would carry no stigma of charity'. ${ }^{31}$

Moreover, the ELFS continued to employ some of their pre-war tactics to put pressure on the government, such as organising demonstrations and sending deputations to government Ministers and governmental bodies where they demanded political and economic rights for working women. For example, when the government introduced the National Register in the summer of 1915, which required the details of everyone between the ages of 15 and 65 and was widely seen as a precursor to compulsory military conscription (which was introduced the year after), the ELFS organised a demonstration which demanded: 'No register without safeguards! No compulsion! Equal pay for men and women! Down with sweating! Wages must rise with prices! Down with high prices and profits! Votes for women to protect our homes and wages! ${ }^{32}$

Barbara Winslow, one of Sylvia Pankhurst's biographers, has argued that instead of organising welfare schemes and deputations to Parliament, 'it might have been better for the ELFS to organize working women and unemployed women to fight for their rights as workers, for better pay and working conditions and for more jobs ${ }^{33}$ Winslow argues that had they focussed on trying to get the women experiencing low pay involved in the struggle they might have generated industrial action and therefore they should have concentrated 'on convincing women munition workers rather than Runciman and Lloyd George ${ }^{34}$ that they deserved equal pay. 'Had there been an organisation of women workers calling for equal pay, backed up with strikes, rallies, and demonstrations, perhaps more could have been accomplished. ${ }^{35}$ This view, however, overlooks the specific difficulties that women workers faced in the munitions industries that become clear when their position is compared with that of the male workers who did undertake significant industrial action in the early years of the First World War. Workers in the munitions factories on the Clyde in Scotland went on strike in February 1915 and again in the spring of that year, while coalminers in South Wales struck in July 1915. Both these groups of workers had been influenced by socialist organisations since before the War and had built a tradition of self-education in socialist ideas; in Scotland John Maclean ran popular classes on Marxism while many of the Welsh workers were involved in the Central Labour College. Consequently, many of the strike leaders were active socialists. The ELFS, as a relatively small organisation formed only months before the War, had nothing like the same degree of influence. Moreover, the war effort saw 1.25 million women enter the workforce. ${ }^{36}$ Therefore large numbers of women were entering the workforce on the terms that employers dictated in wartime. This meant that if women wanted to fight for better conditions they had to engage in an overtly offensive struggle for something they had not had before. By contrast, it is significant that both the first strike on the Clyde and in the South Wales mines were initiated when pre-war pay deals expired and the new offer failed to match the wartime 
rise in the cost of living. ${ }^{37}$ Women workers, new to the industry, did not face the same opportunity of expiring pre-war pay agreements around which to contest their pay. Furthermore, employers took advantage of women workers paying them less than the male workers and forcing them to work excessive hours. This gave rise to resentment among many male workers who responded by harassing women workers and arguing against their employment because they felt women were undercutting and even replacing their jobs leaving them vulnerable to military recruitment. ${ }^{38}$ These tensions were exacerbated by the decision of major unions in the munitions industry, such as the Amalgamated Society of Engineers, to refuse to admit women members, thereby hampering the creation of a struggle of male and women workers to fight collectively for better pay and conditions.

The ELFS's decision to raise industrial demands from outside the workplace perhaps reflected the fact that the workplace could be an uncomfortable environment for women to campaign in. Indeed, Sylvia remembered that the ELFS's July 1915 demonstration against sweated labour was made up of 'the sweated workers come to plead their own cause'. ${ }^{39}$ On the outbreak of war the ELFS had planned more radical, direct action based on their community organising to challenge the economic problems that women faced. At their special committee meeting called two days after the outbreak of war the ELFS voted to endorse the proposal of members Mrs Bird and Miss Paterson to resist the spiralling food prices: 'that someone should go into a shop and ask for food at normal price and if it were refused go and get a member to back her up and go \& take it. ${ }^{40}$

21 Although this took place on a few occasions, Sylvia Pankhurst later recalled that the general atmosphere of demoralisation induced by the War thwarted attempts to transform this into a mass campaign: 'the effect of the War and its sorrows smothered rebellion even against the grossest extortion. ${ }^{41}$ Another proposal that emerged from the special committee meeting was for the rent strike, that the ELFS had been planning prior to the War as a tactic for demanding votes for women, to be implemented with the aim being to halt the rising cost of rent. ${ }^{42}$ While this scheme was not realised by the ELFS, by March 1915 when there was increased anger against the War a militant rent strike campaign and mass resistance to evictions was successfully implemented by women in Glasgow. ${ }^{43}$

\section{Demanding working-class representation}

However, the ELFS's turn towards less direct action on economic questions cannot solely be attributed to a more conservative assessment of what could be achieved. The deputations to governmental bodies, for example, raised the radical prospect of workingclass control over questions previously deemed beyond the concern of democratic decisions. At the start of the War, the government persuaded Mary Macarthur of the National Federation of Women Workers, Marion Phillips and Margaret Bondfield of the Women's Labour League to join the Central Committee for the Employment of Women (CCEW), which provided temporary employment for women. The ELFS was deeply critical of the CCEW's much vaunted scheme, the Queen Mary Workrooms, complaining that the 3d. paid per hour to the workers (considerably less than what the ELFS paid its own employees) meant that leading women in the labour movement were presiding over a scheme that forced working-class women into sweated labour. The ELFS sent a deputation of working women to see Mary Macarthur and argue the case for the payment of a higher wage in the Workrooms. ELFS member Charlotte Drake, herself a member of the 
delegation, reported the exchange in the Dreadnought commenting critically on the " splendid, furnished apartment' in which the deputation was received, with its 'gild chairs' and 'very rich carpets on the floor', observing that Macarthur:

was very affable indeed, shaking hands with us all, and that made me feel very uncomfortable, as I was feeling intensely the contrast between her surroundings and those of the thousands of poor souls that we all know of, who have lost their fathers, brothers and sons and have no comfort of any kind. ${ }^{44}$

Drake's report thus questioned Macarthur's legitimacy to represent the interests of working women when Macarthur was so far removed from everyday working-class experiences, thereby helping to bolster the ELFS's fourth demand that working-class women be themselves representatives on committees on questions related to them.

\section{'It is up to us workers to end the War': campaigning against the War}

The ELFS's insistence on self-representation, which it maintained throughout the War, led to it adopting a more all-encompassing demand than votes for women. In January 1916 they voted to support 'human suffrage', which explicitly demanded votes for all men and women. ${ }^{45}$ Their increasing focus on general working-class representation was reflected in their decision in March 1916 to change their name to the Workers Suffrage Federation (WSF). However, as in the pre-war suffragette campaign, the WSF not only sought to achieve change through winning representation, it also sought change through the self-activity of workers. While the WSF's demand for working-class representation on bodies determining wages and prices held out hope that representation might be able to affect economic conditions, the same could not be said of the question of the War itself which Sylvia had diagnosed as a systemic problem of capitalism. Recalling her feelings in late 1915 Sylvia expressed, in the form of an internal dialogue, the tension between the campaign to win improvements within the existing system, and her desire to challenge that system:

Ruthlessly I examined myself, deciding that though I had spoken against the War, the greater part of my struggle had been waged for economic conditions. "Oh yes, I know this is a capitalist war; if capitalism were ended, wars would be no more; yet the politics of this War, in their callous wickedness; these you have not sufficiently exposed... You have attacked the effects of war and of capitalism more often than those two great causes from which they spring." ${ }^{46}$

When the WSF began to engage in overtly anti-war campaigning from late 1916 they looked to working-class action from below to stop the war. In late February 1917 Melvina Walker was arrested and fined after she addressed a crowd in Hyde Park, telling the audience 'Our class in Germany was just as good as we are. What we want is peace... It is up to us workers to end the War. ${ }^{47}$ Towards the end of 1916 they held peace meetings in the heart of their working-class community, outside the dock gates and in East London's large Victoria Park, while in March 1917 they attempted to sabotage the attempt to recruit workers into the war effort by disrupting the National Service Week rallies held in the East End. ${ }^{48}$ 


\section{Revolutionary democracy and social change}

26

When the Russian Revolution broke out in February $1917^{49}$ it received not only the support of the British left but also support from the British government and The Times newspaper, the organ of establishment opinion in Britain. Their support was based on their understanding of Russia's newly installed Provisional Government. On the one hand the establishment of a Provisional Government appealed to liberal sentiments, not least because it replaced the Tsar, widely seen as the most autocratic leader in Europe, whose alliance with Britain in the War undermined British claims to be fighting for freedom. However, while the British government supported the Provisional Government for the political change it represented, its support was also based on the lack of social change that the new Russian government promised. The Provisional Government's commitment to keeping Russia fighting in the First World War meant that the interests of the British government were unharmed, because it had not lost an ally, but it meant that the heavy cost of war continued to be paid by Russian civilians.

However, the Provisional Government did not have hegemonic power in Russia. Indeed, the February Revolution had produced a situation of 'dual power', which Sylvia analysed in the Dreadnought:

At present there are virtually two Governments in Russia - the Provisional Government [,] appointed by the Duma [,] and the Council of Labour Deputies which is responsible to the elected representatives of the workers and the soldiers. ${ }^{50}$

The councils, or soviets, to which representatives were elected from workplaces and army battalions allowed more direct participation by workers and peasants than the Provisional Government and they increasingly reflected the growing discontent with the War. After the revolutionary anti-war Bolshevik Party won a majority in Russia's two largest cities they called for a second revolution under the slogan 'All power to the soviets'.

After the second Russian Revolution in October 1917 the Bolshevik government ended Russian involvement in the First World War and rapidly instituted radical social reforms, including votes for women, the abolition of legislation that discriminated against children born outside of marriage, civil marriage with equal rights for the husband and wife, the legalisation of abortion and homosexuality.

Sylvia Pankhurst supported the project of extensive social change and she linked the socialist character of these changes and their rapid implementation to the structural change that the soviets represented. She saw the soviets as a more direct form of democracy which could more accurately and swiftly represent the interests of the Russian working class: 'The Soviets, as delegate bodies, are able to respond swiftly to the changing feeling of those they represent. ${ }^{51}$

She argued that this soviet form of democracy was far superior to Parliamentary democracy:

As a representative body, an organisation such as the All-Russian Workers', Soldiers', Sailors', and Peasants' Council is more closely in touch with and more directly represents its constituents than the Constituent Assembly, or any existing Parliament. The delegates to the All-Russian and local Soviets are constantly reporting back to and getting instructions from their constituents; whilst the Members of a Parliament are elected for a term of years and only receive anything approaching to instructions at election times. ${ }^{52}$

Revue Française de Civilisation Britannique, XX-1 | 2015 
These conclusions had implications for Sylvia's campaigning priorities. Whereas previously she had campaigned for universal suffrage within Parliamentary democracy as a means towards fundamental social change which represented working-class interests, when she felt that this was achieved in the aftermath of the October Revolution she argued that a different kind of organisation of society was needed for these changes to be realised. Therefore, although the October Revolution would cause Sylvia Pankhurst to argue for a different kind of democratic structure based on the example the soviets provided her with, her appreciation of the soviets was based on her insistence during the suffragette movement and the First World War that the interests of working-class people could not be accurately represented by others. In the suffragette movement she formed a campaign of working-class suffragettes as she rejected the idea, espoused by the WSPU leadership, that middle-class suffragettes could fight on their behalf. In the First World War she campaigned to expose those who claimed to represent working women were in fact presiding over their exploitation. Therefore, it was not the case that it was only after 1917 that Sylvia Pankhurst was demanding more direct working-class representation, she was demanding this during the First World War and in the suffragette movement before it. The difference from 1917 was that the October Revolution provided her with a model through which she hoped her demand could be realised.

\section{NOTES}

1. The Worker's Dreadnought, 16 February 1918, p. 948.

2. H.M. SWANWICK, I Have Been Young, London: Victor Gollancz, 1935, p. 188.

3. J. LIDDINGTON, The Long Road to Greenham: Feminism and Anti-Militarism in Britain since 1820, London: Virago Press, 1989, p. 96; J. PURVIS, Emmeline Pankhurst: A Biography, London: Routledge, 2002 , p. 271 , p. 283 - Purvis provides a more sympathetic reading of Emmeline Pankhurst's patriotism than the one I have provided here.

4. J. VELLACOTT, Pacifists, Patriots and the Vote: The Erosion of Democratic Suffragism in Britain During the First World War, Basingstoke: Palgrave Macmillan, 2007, pp. 76-9.

5. L. STANLEY with A. MORLEY, The Life and Death of Emily Wilding Davison: A Biographical Detective Story, London: Women's Press, 1988, p. 127.

6. Votes for Women, 25 June 1908, p. 265.

7. Votes for Women, October 1907, p. 6; on this process see K. CONNELLY, Sylvia Pankhurst: Suffragette, Socialist and Scourge of Empire, London: Pluto Press, 2013, pp. 27-30.

8. C. PANKHURST, The Militant Methods of the N.W.S.P.U, London: The Woman's Press, 1908, p. 13.

9. On Christabel Pankhurst's political alliances see M. PUGH, The Pankhursts, London: Allen Lane, 2001, p. 169 and E.S. PANKHURST, The Suffragette Movement: An Intimate Account of Persons and Ideals, London: Virago, 1977, p. 500.

10. PANKHURST, The Suffragette Movement, p. 517.

11. The Woman's Dreadnought, 8 March 1914, p. 3.

12. E.S. PANKHURST, The Home Front: A Mirror to Life in England During the First World War, London: The Cresset Library, 1987, pp. 12-13.

13. The Woman's Dreadnought, 1 August 1914. 
14. The Woman's Dreadnought, 15 August 1914, p. 85.

15. B. Harrison interviews with Miss Elsie Lagsding, 8SUF/B/094, 15 June 1976; Miss Jessie Stephen, 8SUF/B/157, 1 July 1977, Women's Library Recordings, Women's Library Collection, London School of Economics Library.

16. The Workers' Dreadnought, 17 April 1920, p. 1.

17. PANKHURST, The Home Front, p. 16.

18. PANKHURST, The Home Front, pp. 16-17.

19. L. GERMAN, How a Century of War Changed the Lives of Women, London: Pluto Press, 2013, p.18; PANKHURST, The Home Front, p. 18, p. 30.

20. The Woman's Dreadnought, 12 December 1914, p. 155.

21. PANKHURST, The Home Front, p. 205.

22. Minute book of the East London Federation of the Suffragettes, 6 August 1914, E. Sylvia Pankhurst Papers, International Institute of Social History in Amsterdam.

23. The Woman's Dreadnought, 15 August 1914, p. 85.

24. Minutes of ELFS General Meeting, 9 August 1915, E. Sylvia Pankhurst Papers.

25. East London Federation of the Suffragettes. First Annual Report, London: 400 Old Ford Road, Bow, E., 1915, p. 17.

26. Ibid.

27. ELFS. First Annual Report, p. 18.

28. Pankhurst, The Home Front, p. 22.

29. ELFS, First Annual Report, p. 18, see also PANKHURST, The Home Front, p. 22, p. 73.

30. PANKHURST, The Home Front, p. 132.

31. Ibid, p. 43.

32. The Woman's Dreadnought, 10 July 1915, p. 277.

33. B. WINSLOW, 'Sylvia Pankhurst and the Great War', in I. BULLOCK and R. PANKHURST, Sylvia Pankhurst: From Artist to Anti-Fascist, London: Macmillan, 1992, p. 109; see also B. WINSLOW, Sylvia Pankhurst: Sexual Politics and Political Activism, London: UCL Press, 1996, p. 99.

34. Walter Runciman, President of the Board of Trade (1914-1916); Lloyd George, Minister of Munitions (1915-1916), he became Prime Minister at the end of 1916.

35. Ibid, p. 110.

36. GERMAN, How a Century of War Changed the Lives of Women, p. 25.

37. A. MARWICK, The Deluge: British Society and the First World War, London and Hampshire: Macmillan Education, 1991, p. 116.

38. C.A. CULLETON, Working-Class Culture, Women, and Britain, 1914-1921, New York: St. Martin's Press, 1999, p. 34.

39. PANKHURST, The Home Front, p. 202.

40. ELFS Minute Book, 6 Aug. 1914 [u.p], E. Sylvia Pankhurst Papers.

41. PANKHURST, The Home Front, p. 29.

42. ELFS Minute Book, 6 Aug. 1914

43. M. CRAIG, When the Clyde Ran Red, Edinburgh: Mainstream Publishing Company, 2011, pp. 110-13.

44. The Woman's Dreadnought, 3 October 1914, p. 115.

45. ELFS Minutes of General Meetings, 17 January 1916, E. Sylvia Pankhurst Papers.

46. PANKHURST, The Home Front, p. 230.

47. The Woman's Dreadnought, 3 March 1917, p. 688.

48. See East End News, 20 March 1917, press cutting in Tower Hamlets Local History Archive.

49. Before 1918 Russia used the Julian calendar and not the Gregorian calendar used in Western Europe. Therefore, according to the Russian calendar the Russian Revolution broke out on 23 February, according to the Gregorian calendar this was 8 March.

50. The Woman's Dreadnought, 24 March 1917, p. 704. 
51. The Workers' Dreadnought, 26 January 1918, p. 932; on Sylvia Pankhurst's approach to the soviets see also I. BULLOCK, 'Sylvia Pankhurst and the Russian Revolution: the making of a 'LeftWing Communist", in BULLOCK and PANKHURST, Sylvia Pankhurst: From Artist to Anti-Fascist, p. 137.

52. Ibid.

\section{ABSTRACTS}

The rallying of much of the feminist movement to support for the government, and even to enthusiasm for the war in 1914 is well-known. This article looks at a leader of a section of the suffragettes which followed a very different path. Sylvia Pankhurst broke with her patriotic mother and sister to work among working women in the East of London, using dynamic and original forms of activism to defend working women's interests and encourage left wing consciousness.

Le ralliement à la guerre d'une grande partie du mouvement féministe en 1914 est bien connu. Cet article retrace la voie bien différente suivie par une des filles d'Emmeline Pankhurst. Elle militera dans les quartiers ouvriers de Londres et montrera dynamism et originalité dans la défense des intérêts des femmes pauvres.

\section{AUTHOR}

\section{KATHERINE CONNELLY}

University of London, Queen Mary College 